\title{
How Land Finance Affects Green Economic Growth in Chinese Cities
}

\author{
Shiying Hou ${ }^{1}$, Liangrong Song ${ }^{1, *}$, Jiaqi Wang ${ }^{2}$ and Shujahat Ali $^{3}[$ \\ 1 Business School, University of Shanghai for Science and Technology, Shanghai 200093, China; \\ hsy2266@163.com \\ 2 Faculty of Economics and Administration, Universiti Malaya, Kuala Lumpur 50603, Malaysia; \\ s2001909@siswa.um.edu.my \\ 3 Department of Banking and Finance, Mirpur University of Science and Technology, Mirpur 10250, Pakistan; \\ shujahat@must.edu.pk \\ * Correspondence: lrsong1966@163.com
}

Citation: Hou, S.; Song, L.; Wang, J.; Ali, S. How Land Finance Affects Green Economic Growth in Chinese Cities. Land 2021, 10, 819. https:// doi.org/10.3390/land10080819

Academic Editor: Jefferey M. Sellers

Received: 29 June 2021

Accepted: 2 August 2021

Published: 4 August 2021

Publisher's Note: MDPI stays neutral with regard to jurisdictional claims in published maps and institutional affiliations.

Copyright: (C) 2021 by the authors. Licensee MDPI, Basel, Switzerland. This article is an open access article distributed under the terms and conditions of the Creative Commons Attribution (CC BY) license (https:/ / creativecommons.org/licenses/by/ $4.0 /)$.

\begin{abstract}
Land finance is an important means for local governments to develop a regional economy Studying the impact of land finance on green economic growth has important practical significance for achieving high-quality economic growth in China. This article uses panel data from 283 prefecturelevel cities in China to construct a spatial econometric model to study the impact of land finance on green economic growth. The research results show that land finance has a significant inhibitory effect on the growth of the green economy. The direct, indirect and total effects of land finance on green economic growth are all significantly negative, which indicates that the local government's method of making up for the financial funding gap through land finance not only inhibited the green economic growth in the region, but also had an impact on neighboring areas. Local government competition has a regulating effect on the impact of land finance and urban green economic growth, and government competition has actually strengthened the inhibitory effect of land finance on green economic growth. The above conclusions can provide useful practical guidance for optimizing the development of land finance, standardizing local government behavior, and promoting green economic growth.
\end{abstract}

Keywords: land finance; green economic growth; local government competition; spatial econometric model

\section{Introduction}

In order to solve the problems caused by climate and environmental changes in the process of economic development, both developed and developing countries are constantly exploring new methods of sustainable development. The low-carbon economic model characterized by low energy consumption, low pollution and low emissions has been recognized by the world and has formed the development concept of green economy. The essence of green economy is a sustainable economy with coordinated development of ecology and economy. It is an economic growth model characterized by the maintenance of human settlements and the protection of resources and energy. Its purpose is to achieve the coordinated development of environmental protection and economic growth $[1,2]$. In 2011, the Organization for Economic Cooperation and Development (OECD) further explained the meaning of green economic growth. Green economic growth promotes economic growth while ensuring that natural assets can continue to provide various resources and environmental services for human survival [3]. In order to achieve green economic growth, many countries have made major efforts. In 2008, UNEP put forward a global green economy plan that was supported by countries all over the world. In 2012, the British government established the Green Investment Bank to provide financing for companies that develop a green economy. The South Korean government has formulated a 
comprehensive policy framework for green economic growth and invested a lot of money to create green jobs. The Japanese government has formulated a green innovation development strategy, trying to achieve green economic growth by increasing investment in green technology innovation. In addition, some developing countries have also formulated green development strategies. For example, the Indonesian government has increased its total investment in green infrastructure. Mongolia has proposed a series of economic goals for developing green employment and promoting green consumption. In order to solve a series of problems such as resource waste and environmental pollution in the process of China's economic development, the Chinese government also proposed a method to develop a green economy in 2017. The Chinese government has initially formulated some administrative regulations to regulate market behavior. For example, building an energy-saving and emission-reducing production system, restricting enterprise energy consumption and pollution emissions and other market behaviors, encouraging technological innovation to promote green production. In the process of economic development, capital, technology, and labor are the key elements that affect economic growth [4]. Green economic growth needs to take into account the impact of energy and environment on economic growth. It should be noted that although the market has a fundamental role in the allocation of economic resources, the economic system of the public ownership economy determines that the Chinese government still has a strong influence on economic growth. Therefore, the development of China's green economy not only needs to pay attention to the influence of market players, but also needs to focus on the role of government actions on the green economy.

In a market economy, the government intervenes in economic growth through public resources. The government's fiscal revenue and expenditure can not only make up for the lack of market regulation, but also directly affect the distribution of economic production factors $[5,6]$. As a key production factor, land resources play an important role in regional economic growth. Land finance (LF) is the behavior of local governments intervening in the allocation of regional economic resources through the transfer of land use rights $[7,8]$. Its main purpose is to maintain the sustainable development of local fiscal expenditures. The funds obtained by local governments through LF can be mainly divided into two categories. The first is the land transfer income, which is the acquisition of cultivated land by the local government at a low price, which it then sells to the market at a high price through bidding, auction, and listing $[9,10]$. This has brought huge amounts of land transfer income to local governments. It should be noted that most of the land requisitioned by local governments is cultivated land. The market price of cultivated land is much lower than the market price of industrial land and residential buildings. This price difference is a key factor for local governments to attach importance to LF [11]. The second type is land tax and fee income, which is some tax and fee income obtained by the local government through the development of land and its attachments [12,13]. Due to the difference in taxation systems, the land property taxes implemented by many countries are also different. Especially in China, the ownership of land belongs to the government, and the local government does not get more land property tax, but mainly relies on the land transfer income. In addition, due to the restrictions of the fiscal decentralization system, China's local governments have a serious imbalance in fiscal revenue and fiscal expenditure. Local governments have a strong demand for LF and mainly rely on increasing land supply to create income to meet financial needs [14].

Although the mechanism of LF through expropriation and resale is unsustainable because the amount of peri-urban land is finite, LF has become the main source of local government revenue. In 2020, the total transaction price of China's land transfer will exceed 8.4 trillion yuan, and the land transfer revenue will account for $84.03 \%$ of the local general public budget. This shows that LF is a key factor in regional economic growth. LF not only directly affects the growth of the regional economy, but also affects the development of the regional economy by influencing industrial structure, urbanization and industrialization $[7,8]$. Local governments use funds obtained from land financing to 
make large-scale investments in regional public infrastructure and promote the process of regional urbanization [11]. In addition, local governments allocate land resources, provide land concessions for domestic and foreign capital to build factories, improve China's industrial system, and promote the development of industrialization [15]. For the growth of the regional economy, urbanization and industrialization are conducive to the highspeed growth of the Chinese economy. However, the rapid development of urbanization and industry may also have a greater impact on the regional ecological environment [16]. Especially under the extensive management model with high resource dependence, the development model of high energy consumption and high emission is essentially an unsustainable behavior that sacrifices the regional ecological environment in exchange for economic development. In China, this unsustainable economic strategy is inseparable from the support of local governments [17]. Therefore, the development of China's green economy not only requires local governments to maintain stable regional economic growth, but also pay attention to the coordination between the environment and the economy. However, while taking into account the quality of the regional environment, what is the impact of LF on the growth of the green economy? Clarifying the impact mechanism of LF on green economic growth not only achieves the coordination of economic construction and ecological civilization construction, but also can provide practical experience for the high-quality transformation of China's economy.

\section{Literature Review}

Green economic growth mainly reflects the coordinated development of economic growth and the ecological environment [18]. The methods used to evaluate green economic growth mainly include the subjective evaluation analysis method and non-parametric estimation method. Among them, the subjective evaluation method is to use fuzzy evaluation and tomographic analysis to construct a green economy evaluation index system. The evaluation index system of green economic growth mainly includes environmental issues, natural resources, policy interventions, energy consumption and pollution control, etc. $[3,19,20]$. However, the index setting of the subjective evaluation method is easy to be interfered by the subjectiveness of people which affects the fairness of the results [21]. In the non-parametric estimation method, the data envelopment analysis (DEA) method has attracted the attention of researchers [22,23]. It is mainly calculated by the input factors and output factors of green economic growth. Among them, the input factors are mainly production factors such as capital, labor, technology, energy, and land. The expected output factors are mainly GDP, industrial added value, etc. Undesired output factors are mainly concentrated in industrial waste gas, industrial wastewater and other pollutants [24]. In addition, scholars have also studied the influencing factors of green economic growth They studied the influence of natural resource constraints, green technological innovation, green finance, environmental regulations and government behaviors on the growth of green economy from the perspectives of technology, resources, capital, institutions and government preferences [25-28].

Green economy is an organic unity of economic and environment. The impact of LF on the green economic growth mainly reflects both economic and environmental effects. In terms of the economic effects of LF, scholars have mainly studied the direct effects of LF on the economic growth and effects of LF by affecting urbanization, industrialization, industrial structure, and foreign investment $[9,14,29]$. At the same time, it should be noted that the land finance model of the Chinese government is different from that of other countries. China's land finance mainly relies on local governments to increase the scale of land transfers to obtain land transfer fees, while other countries pay more attention to land property taxes [29]. Scholars mainly analyzed the environmental effects of LF from the perspectives of carbon emissions, industrial agglomeration, and urbanization. Wang et al. (2020) believes that there is a non-linear relationship between LF and urban carbon emissions [30]. Among them, economic level and industrial structure are key factors [11]. Wassmer (2002) believes that the expansion of LF has aggravated environmental pollution, 
and low-level environmental regulations will stimulate the expansion of LF and aggravate the pollution effect of LF [31]. On this basis, Weingas (2009) studied the competition phenomenon of LF, and found that the low-level environmental regulation caused by competition will stimulate the expansion of the LF scale and aggravate environmental pollution [32]. Kahn et al. (2021) believes that local governments use LF to attract foreign investment and establish many industrial parks, which promotes industrial agglomeration [33]. However, it should be noted that industrial agglomeration will increase the scale of production, which will accelerate the rate of resource consumption and deteriorate the ecology of the agglomeration [34]. Finally, LF provides the primitive accumulation of capital for urbanization and meets the infrastructure construction required for urbanization. However, the rapid advancement of urbanization has caused pollution of the ecological environment, and there is an inverted $\mathrm{U}$-shaped relationship between urbanization and the ecological environment [35].

Through a literature review, it was found that scholars have conducted research on green economic growth and land finance, but there are relatively few direct studies on the relationship between LF and green economic growth. Therefore, we incorporate economic growth and the ecological environment into a unified framework to study the relationship between LF and regional green economic growth, which is mainly to clarify the impact mechanism of LF on a regional green economy. The contribution of this article may be reflected in three aspects. First, we have brought economic growth and the ecological environment into a unified framework, and systematically studied the relationship between LF and the green economy's efficiency. Second, because of China's fiscal decentralization system, regional governments may have strategic behaviors in the allocation of land resources. This means the impact of LF on the growth of the green economy may have a spatial effect. Therefore, we have constructed a spatial econometric model to analyze it, which is conducive to improving the accuracy and credibility of the research conclusions. Third, government competition may have an impact on the allocation of financial resources and economic development. We further analyzed the regulatory effect of local government competition on the relationship between LF and green economic development. It helps to better understand the impact of LF on green economic growth from a political perspective.

\section{Research Hypothesis}

Land finance reflects the interest redistribution relationship formed by local governments affecting fiscal expenditures through land distribution. The influence of LF on the growth of green economy can be analyzed in terms of inhibition and promotion.

In terms of the positive role of LF, LF provides a source of funds for local investment and construction, and became an important driving force for regional economic growth First of all, local governments use cheap land transfers as a means to attract investment and promote investment growth and economic expansion. The advanced technologies and products brought by FDI improve the environmental level of the region through the spillover effects of green technology, and ultimately promote the development of the regional green economy [9]. Second, local governments have sold land at high prices to increase extra-budgetary income, providing financial support for urban development and infrastructure construction [36]. If the land fiscal revenue is used in the field of public service expenditures such as energy conservation and environmental protection while taking into account economic development, then the development of the urban green economy is showing a rising trend under the influence of LF. Finally, local governments provide basic guarantees for urban expansion through land transfers, conducive to the development of the real estate industry and construction industries, and increase tax revenues [37]. This allows local governments to have more funds to treat local pollution and build environmental protection facilities. In addition, high income levels and a good urban environment can promote the development of the tertiary industry in the region and achieve the goal of optimizing the industrial structure [7]. It will help reduce pollution 
from the secondary industry, increase the disposable income of local governments, and promote regional green economic growth.

From the perspective of the restraining effect of LF, as an important part of production factors, the use of land elements should follow the basic economic laws regulated by the market. However, LF strengthens the power of local governments in the allocation of land resources, which can easily cause the distorted allocation of land resources. If the local government pays too much attention to the economic growth rate in the region, then the local government will be more inclined to transfer land as industrial land to achieve the goal of economic growth. This has led to the excessive development of capital-intensive industries and heavy industries, aggravated the distortion of resource consumption and allocation, reduced the quality of the urban environment, and affected the development of urban green economy [38]. In addition, land is a scarce resource, and this attribute determines the unsustainability of the land financial development model [39]. Local governments increase the scale of land acquisition and supply through the establishment of new urban areas, industrial parks, and development zones, which may lead to rapid land urbanization and disorderly expansion of urban space. The disorderly expansion of urban space has not only reduced the urban green area and increased the consumption of resources, but also led to environmental destruction and a decline in ecological functions [33]. These will affect the sustainable development of the regional green economy.

Hypothesis 1 (H1). Land finance promotes regional green economic growth.

Hypothesis 2 (H2). Land finance inhibits regional green economic growth.

Under the dual pressure of imbalanced fiscal revenue and expenditure and official evaluation, local governments are the main participants in LF and regional green economic growth. The behavior of local governments is closely related to LF and regional green economic growth [40]. This is mainly because LF is the off-budget revenue of local governments, and local governments have greater control over LF funds and land resources. When local governments use LF to develop regional economies under fiscal pressure, governments in other regions will also imitate this behavior based on their own interests [41]. This will increase the dependence of local governments on LF at the same time, because economic growth is the primary criterion for performance evaluation and promotion of officials. In order to meet the needs of political promotion, local government officials often spare no effort to use land resource allocation rights to obtain land transfer income, promote the rapid growth of the regional economy and obtain a better GDP growth ranking [42]. In the end, under the dual effects of fiscal pressure and promotion pressure, a land fiscal development model that competes for growth has been formed. However, this land competition model will not only be reflected in the aspects of investment promotion, industrial development, urbanization and industrialization, but also in the increasing social welfare and environmental protection. The reasonable competition of local governments will promote the positive effect of LF on the growth of the regional green economy, while the disorderly vicious competition will amplify the restraining effect of LF on green economy. Therefore, the local government not only faces its own financial pressure but also competition from neighbors in the process of using LF to develop the regional economy. In addition, due to differences in regional resources and economic scale, land finance will also show distinct characteristics in competition among local governments [43]. These factors lead to local government competition behaviors that may have a greater impact on the role of LF.

Hypothesis 3 (H3). Local government competition has a regulating effect on the impact of land finance on green economic growth. 


\section{Research Design}

\subsection{Model Setting}

In the process of analyzing the impact of LF on green economic growth, it is necessary to pay more attention to the possible strategic interactions between local governments. The spatial econometric model provides a good identification strategy for research. Spatial econometrics is a branch of econometrics. It studies how to deal with spatial interaction (spatial autocorrelation) and spatial structure (spatial inhomogeneity) of structural analysis in the regression model of the cross-sectional data and panel data. It is a model that analyzes the spatial effect of the explained variable on the explanatory variable. It can not only measure the direct impact of land finance on the growth of green economy, but also the indirect impact of land finance on the growth of green economy in neighboring areas. Therefore, we construct a spatial panel regression model to analyze the impact of LF on green economic growth.

$$
G E_{i t}=\alpha_{0}+\alpha_{1} L F_{i t}+\alpha_{2} w L F_{i t}+\alpha_{3} \text { control }_{i t}+\eta_{t}+\mu_{i}+\varepsilon_{i t}
$$

In Formula (1), GE represents green economic growth, $i$ represents different regions, $t$ represents time, and $\alpha_{0}$ is the intercept term. LF represents land finance, and $\alpha_{1}$ is the corresponding estimated coefficient. $w$ is a normalized spatial weight matrix with $n * n$ diagonal elements being 0 . This article sets a $0-1$ binary space weight matrix based on the spatial adjacency relationship of the city. When area $i$ and area $j$ are adjacent, $w_{i j}=1$, otherwise, $w_{i j}=0 . \alpha_{2}$ indicates the impact of LF in neighboring areas on the growth of the green economy in the region. If $\alpha_{2}$ is greater than 0 and the significance test is passed, it indicates that LF has a positive effect on green economic growth. On the contrary, LF will inhibit the growth of the green economy. control is the control variables selected in this paper, and $\alpha_{3}$ is the corresponding estimated coefficient. $\eta$ and $\mu$ indicate unobservable time fixed effects and regional fixed effects. $\varepsilon$ represents the random error term.

\subsection{Data and Variables}

The empirical research in this paper selects panel data from 283 prefecture-level cities in China from 2009 to 2018 (excluding cities with missing data such as Lhasa, Sansha, Haidong, Chaohu, Longnan, and Zhongwei). The reason why we choose prefecture-level cities in China as our sample is because prefecture-level cities have greater influence and execution power in the process of regional governance, and directly determine the allocation of regional land resources. The sample data mainly come from China City Statistical Yearbook, China Land and Resources Statistical Yearbook, China Fiscal Yearbook and China Environment Statistical Yearbook.

\subsubsection{Explained Variable: Green Economic Growth (GE)}

Reducing resource consumption and pollutant emissions while maintaining economic growth is generally considered to be an important way to achieve green economic growth. The calculation of green economic growth variables needs to take into account both economic growth and ecological environment, and consider the expected output and undesired output in the economic output [44]. This article draws on the research experience of $\mathrm{Wu}$ et al. (2013) and uses the super-sbm model of undesired output to measure the efficiency of the green economy to refer to the level of green economic growth in the region [45]. We use the super-sbm model to measure green economic growth by analyzing the input production factors and output efficiency in the process of green economic growth. It means that the government or enterprise invested capital, technology, labor, energy and other elements to produce, and finally produced the expected economic growth and undesired environmental pollutants. The super-SBM model is a method that combines super efficiency with the SBM model. Compared with the data envelopment analysis (DEA) model based on linear programming and using distance function as the method, the super-SBM model takes into account the slack of input and output, which helps to improve the accuracy of 
the calculation of green economic growth. The method of super-SBM model to measure green economic growth is shown in Formulas (2) and (3).

Assuming there are $n$ decision-making units (DUM), each DUM contains $m$ kinds of input elements, $z$ kinds of expected outputs and $s$ kinds of undesired outputs, then each element input $x$ of DUM can be represented by $x=\left(x_{1}, x_{2}, x_{3} \ldots x_{N}\right) \in R_{m}^{+}$. Expected output $y^{a}$ can be represented by $y^{a}=\left(y_{1}^{a}, y_{2}^{a}, y_{3}^{a} \ldots y_{M}^{a}\right) \in R_{z}^{+}$, and undesired output $y^{b}$ can be represented by $y^{b}=\left(y_{1}^{b}, y_{2}^{b}, y_{3}^{b} \ldots y_{s}^{b}\right) \in R_{s}^{+}$. Among them, $x, y^{a}, y^{b}$ are all greater than 0 . The production possibility set of the $k$ area in the $t$ period can be defined as the Formula (2),

$$
P_{t}\left(x_{t}\right)=\left\{\left(x_{k, t}, y_{k, t}^{a}, y_{k, t}^{b}\right) \mid x_{t, k, n} \geq \lambda_{t, k} X, y_{t, k, m}^{a} \leq \lambda_{t, k} Y^{a}, y_{t, k, s}^{b} \geq \lambda_{t, k} Y^{b}\right\}
$$

Among them, $\lambda_{t, k}$ represents the weight vector. The super-SBM model is constructed as Formula (3), which takes into account the undesired output.

$$
\rho=\min \frac{\frac{1}{m} \sum_{i}^{m} \frac{\overline{x_{i}}}{\bar{x}_{i k}}}{\frac{1}{z+s}\left(\sum_{\gamma=1}^{z} \frac{\overline{y^{a}}}{\bar{y}_{\gamma k}^{a}}+\sum_{v=1}^{s} \frac{\overline{y^{b}}}{y_{v k}^{b}}\right)} \text { s.t. }=\left\{\begin{array}{l}
\bar{x} \geq \sum_{j=1, \neq k}^{n} \lambda_{j} x_{i j} \\
\overline{y^{a}} \leq \sum_{j=1, \neq k}^{n} \lambda_{j} y_{i j}^{a} \\
\overline{y^{b}} \geq \sum_{j=1, \neq k}^{n} \lambda_{j} y_{i j}^{b} \\
\bar{x} \geq x_{k}, \overline{y^{a}} \leq y_{k}^{a}, \overline{y^{b}} \geq y_{k}^{b}, \lambda \geq 0
\end{array}\right.
$$

In Formula (3), $n$ represents the number of decision-making units, $m$ represents input, $z$ and $s$ represent expected and undesired output. $x$ presents the element in the corresponding input matrix. $y^{a}$ and $y^{b}$ represent the elements in the corresponding expected and undesired output matrix. $\rho$ is the calculation result of green economic growth.

In order to calculate the green economic growth, the input variables we selected mainly include labor, capital, and energy. We use the annual urban employment number to represent labor input. Capital investment adopts fixed asset investment, and uses the perpetual inventory method to account for it as a stock form. Energy input is expressed in terms of total energy consumption. Output can be divided into two parts, expected and undesired. Expected output is economic output expressed in terms of regional GDP. Unexpected output is expressed in terms of $\mathrm{SO}_{2}$ emissions and $\mathrm{CO}_{2}$ emissions in industry and life, which is consistent with the reality of China.

\subsubsection{Explanatory Variable: Land Finance (LF)}

Land finance not only includes land transfer income, but also involves land-related real estate taxes and bank income obtained by mortgaged land. Among them, land transfer revenue accounts for the largest proportion of land finance, and the government has strong independent control over it. In addition, because China's land finance does not rely on land property taxes. Therefore, we use local government land transfer revenue as a proxy variable for land finance, and in order to eliminate the difference in the economic scale of each city, we use the ratio of land transfer revenue to public fiscal revenue to eliminate scale differences.

\subsubsection{Regulated Variables}

To analyze the impact of local government competition on the role of land finance, we further select the interactive variables $\left(g o v^{*} L F\right)$ composed of local government competition (gov) and land finance (LF) to analyze the regulation effect. At the same time, because the main purpose of local government competition is to satisfy the performance evaluation of officials by gaining advantages in economic growth. We choose the difference between the urban GDP growth rate and the GDP growth rate of the highest provinces in the adjacent area to measure local government competition behavior variables. The greater the difference between them, the greater the pressure on the performance evaluation of local 
governments. The competition among local governments becomes fiercer. This not only reflects the pressure of regional economic development, but also conforms to the current performance evaluation model and the purpose of competing for growth. In addition, we take into account the time lag of the policy, and deal with GDP lagging one period.

\subsubsection{Control Variables}

Other variables affecting green economy growth include fiscal decentralization, environmental regulations, industrial structure, foreign investment, urbanization, and human capital. (1) Fiscal decentralization (fiscal). The income method is used to measure the degree of fiscal decentralization. The specific accounting method is per capita local fiscal revenue / (per capita local fiscal revenue + per capita central fiscal revenue). (2) Environmental regulations (env). The investment in urban industrial pollution control during the inspection period is selected as its measurement index. (3) Industrial structure (str). Expressed by the proportion of the output value of the secondary industry. (4) Foreign direct investment (fdi). Expressed by the amount of direct investment. (5) Urbanization $(u r b)$. Expressed by the proportion of urban population. (6) Human capital (human). The selected measure is the average years of education. Table 1 shows the calculation methods and data sources of variables.

Table 1. The calculation methods and data sources of variables.

\begin{tabular}{|c|c|c|}
\hline Variable & Statistical Methods & Data Sources \\
\hline GE & $\begin{array}{l}\text { Select the input variables and output variables of the green economy, and } \\
\text { use the data envelopment analysis (DEA) method to calculate. }\end{array}$ & \multirow{9}{*}{$\begin{array}{l}\text { The sample data mainly come from China } \\
\text { City Statistical Yearbook, China Land and } \\
\text { Resources Statistical Yearbook, China } \\
\text { Fiscal Yearbook and China Environment } \\
\text { Statistical Yearbook. }\end{array}$} \\
\hline$L F$ & Expressed by local government land transfer income. & \\
\hline gov & $\begin{array}{l}\text { Expressed by the difference between the urban GDP growth rate and the } \\
\text { GDP growth rate of the highest provinces in neighboring regions. }\end{array}$ & \\
\hline fiscal & $\begin{array}{c}\text { Expressed as the ratio of the regional per capita fiscal revenue to the } \\
\text { national per capita fiscal revenue. }\end{array}$ & \\
\hline env & $\begin{array}{c}\text { Expressed by the investment in the treatment of urban } \\
\text { industrial pollution. }\end{array}$ & \\
\hline str & $\begin{array}{l}\text { Expressed by the proportion of the output value of the } \\
\text { secondary industry. }\end{array}$ & \\
\hline fdi & Expressed by the amount of direct investment. & \\
\hline$u r b$ & Expressed by the proportion of urban population. & \\
\hline human & Expressed by the average years of education. & \\
\hline
\end{tabular}

In addition, we consider that there may be multicollinearity and heteroscedasticity between variables. Therefore, the variance inflation factor (VIF) test was performed on the variables according to the basic model (1). The result shows that the VIF value is 1.82, which shows that the problem of multicollinearity can be ignored. At the same time, because we have processed all variables logarithmically in the empirical regression. It helps to eliminate the influence of heteroscedasticity, and the $p$-value of White's test is 0.7934 , which cannot reject the original hypothesis with the same variance. Table 2 is descriptive statistical results.

Table 2. Descriptive statistics of variables.

\begin{tabular}{ccccccc}
\hline Variable & Unit & Obs & Mean & Std. Dev. & Min & Max \\
\hline GE & 1 & 2830 & 0.957 & 0.052 & 0.793 & 1.203 \\
LF & 1 & 2830 & 0.487 & 0.280 & 0.093 & 1.796 \\
gov & 100 & 2830 & 2.589 & 1.786 & 0.454 & 8.433 \\
fiscal & 1 & 2830 & 0.498 & 0.145 & 0.252 & 0.876 \\
env & 100 million-yuan & 2830 & 2.456 & 6.832 & 0.124 & 22.569 \\
str & 1 & 2830 & 1.123 & 0.381 & 0.477 & 2.772 \\
urb & 100 & 2830 & 53.178 & 12.356 & 30.872 & 89.481 \\
fdi & billion-yuan & 2830 & 113.295 & 161.115 & 1.865 & 638.792 \\
huamn & year & 2830 & 8.723 & 0.874 & 6.061 & 12.087 \\
\hline
\end{tabular}




\section{Analysis and Discussion of Empirical Results}

\subsection{Spatial Autocorrelation Test}

Empirical analysis using spatial econometric models needs to make it clear whether the variables have spatial autocorrelation. If the test results show that there is spatial autocorrelation of urban green economic growth, then the choice of spatial measurement model is appropriate. The global Moran index is the main tool to test the spatial autocorrelation, and the calculation of Moran's I is Formula (4).

$$
I=\frac{\sum_{i=1}^{n} \sum_{j=1}^{n} w_{i j}\left(x_{i}-\bar{x}\right)\left(x_{j}-\bar{x}\right)}{S^{2} \sum_{i=1}^{n} \sum_{j=1}^{n} w_{i j}}
$$

Among them, $S^{2}=\frac{1}{n} \sum_{i=1}^{n}\left(x_{i}-\bar{x}\right)^{2} \bar{x}=\frac{1}{n} \sum_{i=1}^{n} x_{i}, x_{i}$ represents the urban green economic growth level, $n$ represents the number of samples, and $w$ is the spatial weight matrix. The value range of Moran's $I$ is $[-1,1]$. When Moran's $I>0$, it means that the green economic growth of the neighboring areas is positively correlated. When Moran's $I=0$, it means that there is no correlation between green economic growth in neighboring areas. When Moran's $I<0$, it indicates that there is a negative correlation between the green economic growth of the neighboring areas.

Table 3 show the global Moran's I of each city during 2009-2018 was between 0.253 and 0.324 . This means that the green economic growth of each city has the characteristics of positive spatial autocorrelation, and the surrounding cities with a high level of green economic growth will inevitably gather a large number of cities with a high level of green economic growth. Therefore, we can use the spatial measurement model.

Table 3. Moran's I of green economic growth in 2009-2018.

\begin{tabular}{cccc}
\hline Year & Moran's $\boldsymbol{I}$ & Z-Statistic & $p$-Value \\
\hline 2009 & 0.253 & 2.318 & 0.012 \\
2010 & 0.276 & 2.105 & 0.026 \\
2011 & 0.261 & 1.896 & 0.074 \\
2012 & 0.283 & 2.719 & 0.004 \\
2013 & 0.296 & 1.933 & 0.049 \\
2014 & 0.311 & 2.164 & 0.024 \\
2015 & 0.305 & 1.925 & 0.050 \\
2016 & 0.317 & 2.218 & 0.020 \\
2017 & 0.297 & 2.271 & 0.017 \\
2018 & 0.324 & 2.115 & 0.028 \\
\hline
\end{tabular}

\subsection{The Specific Form of the Model}

Due to the significant spatial autocorrelation of green economic growth, we have to verify the specific form of the selected spatial measurement model. The Lagrangian multiplier test (LM) and robust LM test can be used to test the specific form of the spatial measurement model [46]. If they are all significant, the spatial measurement model can be used as the benchmark model. Otherwise, we can only use the ordinary panel model for basic analysis. The test results found that LM (lag) and robustness LM (lag) have larger values and are more significant. This shows that the LM (lag) and robustness LM (lag) of the spatial lag model (SLM) are better than the spatial error model (SEM), we choose the SLM model. In addition, the likelihood ratio LR passes the $1 \%$ test, and we need to control the time and individual fixed effects in the model. Table 4 is the test result of LM. 
Table 4. LM test results.

\begin{tabular}{ccc}
\hline Test & Statistic & $p$-Value \\
\hline Lagrange multiplier (error) & 6.479 & 0.061 \\
Robust Lagrange multiplier (error) & 53.285 & 0.001 \\
Lagrange multiplier (lag) & 31.144 & 0.002 \\
Robust Lagrange multiplier (lag) & 94.127 & 0.000 \\
\hline
\end{tabular}

\subsection{Analysis of Empirical Results}

The regression analysis in this article is realized by stata13. To facilitate the analysis of the results, we report the results of different fixed effects of the different models. Among them, SLM is the Formula (1) model, OLS is the ordinary least squares model in econometrics, $s f$ represents the individual fixed effect, $t f$ represents the time fixed effect, and $s t f$ represents the individual and time fixed effects.

The results in Table 5 show that the coefficients of LF variables in the regression results of the OLS model and the SLM model are both less than 0, and at least passed the $10 \%$ level of significance test. This shows that LF restrained the city's green economic growth during the sample period. The spatial correlation coefficients $(p)$ are all greater than 0 , and have passed the $1 \%$ significance test. This indicates that there is a strong spatial correlation in the growth of the green economy during the sample period. In addition, we compared the results of the OLS model and the SLM model and found that the individual and time dual fixed effects of the SLM model have more advantages in the significance of key variables. Therefore, we mainly analyze the regression results of the SLM model's dual fixed effects. In the results of column (4) in Table 5, the coefficient of the LF variable is -0.387 , and it has passed the $5 \%$ significance test. The spatial coefficient of LF is -0.401 , which also passes the $1 \%$ level of the significance test. It shows that LF has restrained the green economic growth in Chinese cities, and research Hypothesis 2 has been proved. Observing the results of the control variables, we find that fiscal decentralization, foreign direct investment, and industrial structure have an inhibitory effect on green economic growth. However, environmental regulations, urbanization, and human capital can promote green economic growth.

In order to further clarify the spatial effect of LF on the growth of green economy, we use the method of Lesage and Pace (2009) to decompose the spatial effect using the partial differential method [46]. It can specifically decompose the effect of land finance on green economic growth into direct effects, indirect effects and total effects. Among them, the direct effect reflects the impact of LF on the growth of the green economy in the region. The indirect effect represents the spatial impact of surrounding urban LF on the growth of the green economy in the region, and it reflects the spatial spillover effect. If the coefficient of direct effect is greater than 0 , it indicates that LF can promote the growth of the green economy in the region. Otherwise, LF will inhibit the growth of the green economy. Similarly, the coefficient of indirect effect represents the spillover effect of LF on the green economic growth of the adjacent area. The results are shown in Table 6.

In Table 6, the impact coefficients of the direct and indirect effects of LF on the growth of the green economy are -0.183 and -0.249 , both of which have passed the significance test. This shows that LF not only has a restraining effect on the growth of the green economy in the region, but also has a restraining spillover effect on the growth of the green economy in neighboring areas. The main reason is that LF easily causes the distorted allocation of land resources. Under the influence of the fiscal decentralization system, in order to obtain more extra-budgetary funds, local governments may focus on guiding the development of high-polluting and high-energy-consuming industries with large scale, low risk, and sufficient tax sources. This will aggravate environmental pollution and inhibit regional green economic growth. This is consistent with Wang (2020) research on the spatial effects of land finance on carbon emissions. Land finance stimulates the total amount of urban carbon emissions, increases the economic cost of environmental governance, and spreads to neighboring areas [30]. At the same time, local governments increase the scale of land 
acquisition and supply through the establishment of new urban areas, industrial parks, and development zones, which may lead to disorderly expansion of urban space. The disorderly expansion of cities has not only reduced the urban green area and increased the consumption of resources, but also led to environmental damage and decline in ecological service functions. This research conclusion proposed by Han (2020) that urban expansion will lead to environmental degradation has also been strongly confirmed [47]. Therefore, research Hypothesis 2 has been more fully demonstrated.

Table 5. Analysis of regression results.

\begin{tabular}{|c|c|c|c|c|}
\hline & (1) & (2) & (3) & (4) \\
\hline & OLS & SLM (sf) & SLM (tf) & SLM (stf) \\
\hline$L F$ & $\begin{array}{l}-0.298 * \\
(-1.85)\end{array}$ & $\begin{array}{c}-0.334 \text { ** } \\
(2.36)\end{array}$ & $\begin{array}{l}0.351 \\
(1.50)\end{array}$ & $\begin{array}{c}-0.387^{* *} \\
(-2.15)\end{array}$ \\
\hline$w \times L F$ & & $\begin{array}{c}-0.294 \text { * } \\
(1.74)\end{array}$ & $\begin{array}{l}-0.373 \\
(-0.98)\end{array}$ & $\begin{array}{c}-0.401^{* * *} \\
(-3.36)\end{array}$ \\
\hline fiscal & $\begin{array}{c}-0.186^{*} \\
(-1.74)\end{array}$ & $\begin{array}{c}-0.232 * \\
(-1.69)\end{array}$ & $\begin{array}{l}-0.238 \text { * } \\
(-1.82)\end{array}$ & $\begin{array}{c}-0.272^{* *} \\
(-2.42)\end{array}$ \\
\hline env & $\begin{array}{l}-0.012 * \\
(-1.92)\end{array}$ & $\begin{array}{c}0.004^{* *} \\
(2.11)\end{array}$ & $\begin{array}{c}-0.013^{* *} \\
(-2.01)\end{array}$ & $\begin{array}{c}0.002 * * \\
(2.51)\end{array}$ \\
\hline$f d i$ & $\begin{array}{c}0.014^{* *} \\
(2.12)\end{array}$ & $\begin{array}{l}0.006 \\
(1.53)\end{array}$ & $\begin{array}{l}-0.008^{*} \\
(-1.73)\end{array}$ & $\begin{array}{l}-0.011 \\
(-0.52)\end{array}$ \\
\hline str & $\begin{array}{l}-0.010 * \\
(-1.90)\end{array}$ & $\begin{array}{l}-0.007 * \\
(-1.91)\end{array}$ & $\begin{array}{c}-0.006^{* *} \\
(-2.35)\end{array}$ & $\begin{array}{c}-0.008^{* *} \\
(-2.29)\end{array}$ \\
\hline$u r b$ & $\begin{array}{l}0.014 \\
(1.65)\end{array}$ & $\begin{array}{c}0.013^{* *} \\
(2.18)\end{array}$ & $\begin{array}{c}-0.017 \\
(0.86)\end{array}$ & $\begin{array}{c}0.020 * * \\
(2.51)\end{array}$ \\
\hline human & $\begin{array}{c}0.043 * * \\
(2.04)\end{array}$ & $\begin{array}{l}0.022 * \\
(1.80)\end{array}$ & $\begin{array}{l}0.038^{*} \\
(1.93)\end{array}$ & $\begin{array}{c}0.043 \text { * } \\
(1.77)\end{array}$ \\
\hline _cons & $\begin{array}{c}0.318^{* * *} \\
(2.69)\end{array}$ & & & \\
\hline$\rho$ & & $\begin{array}{c}0.263^{* * *} \\
(3.24)\end{array}$ & $\begin{array}{c}0.235^{* * * *} \\
(3.19)\end{array}$ & $\begin{array}{c}0.290^{* * *} \\
(3.36)\end{array}$ \\
\hline sigma2 & & $\begin{array}{c}0.011^{* * *} \\
(10.21)\end{array}$ & $\begin{array}{c}0.012^{* * *} \\
(10.20)\end{array}$ & $\begin{array}{c}0.012^{* * *} \\
(10.21)\end{array}$ \\
\hline R2 & 0.498 & 0.537 & 0.541 & 0.544 \\
\hline $\log -L$ & & 434.81 & 429.51 & 439.26 \\
\hline
\end{tabular}

Note: ${ }^{* * *}, * *$, and ${ }^{*}$ represent significance of $p$-values at 1,5 , and $10 \%$, respectively.

Table 6. Decomposition of spatial effects.

\begin{tabular}{ccccc}
\hline Type & Variables & Coef. & T-Value & $p$-Value \\
\hline Direct effects & & -0.183 & 2.38 & 0.031 \\
Spatial spillover effects (indirect effects) & $L F$ & -0.249 & 2.12 & 0.044 \\
Total effects & & -0.432 & 2.20 & 0.036 \\
\hline
\end{tabular}

\subsection{The Impact of Government Competition}

As a major participant in LF and regional green economic growth, the local government's actions are very important. To study the regulatory effects of local government competition. We introduced the interaction variable $(L F \times$ gov $)$ between local competition and LF in the basic model to test the regulating effect of local government competition.

The results in Table 7 show that we have added the variable of government competition behavior to the model, but LF still has a restraining effect on green economic growth. In addition, the coefficient of local government competition is also negative. This shows that the competition of local governments in pursuit of economic speed has restrained green economic growth. At the same time, the interaction variable coefficient of LF and government competition behavior is significantly positive, which shows that government competition behavior positively regulates the effect of LF on urban green economic growth. However, LF has inhibited the growth of the green economy, and government competition 
has actually expanded the inhibiting effect of LF. In addition, we observe the results of the spatial term. The variable coefficients of LF and government competition behavior are both less than 0 , which shows that government competition has an inhibitory effect on the green economic growth of neighboring areas, and the interactive effect also expands the spatial restraint of LF. Therefore, Hypothesis 3 can be demonstrated.

Table 7. The regulating effect of local government competition.

\begin{tabular}{|c|c|c|c|}
\hline & (1) & (2) & (3) \\
\hline & SLM (stf) & SLM (stf) & SLM (stf) \\
\hline$L F$ & $\begin{array}{c}-0.387^{* *} \\
(-2.15)\end{array}$ & $\begin{array}{c}-0.269 * * \\
(-2.20)\end{array}$ & $\begin{array}{c}-0.394 * * \\
(-2.19)\end{array}$ \\
\hline$W \times L F$ & $\begin{array}{c}-0.401 * * * \\
(-3.36)\end{array}$ & $\begin{array}{c}-0.320 * * * \\
(-2.85)\end{array}$ & $\begin{array}{c}-0.417 * * * * \\
(-2.77)\end{array}$ \\
\hline gov & & $\begin{array}{c}-0.116^{* *} \\
(-2.28)\end{array}$ & \\
\hline$W \times g o v$ & & $\begin{array}{c}-0.240 * \\
(2.11)\end{array}$ & \\
\hline$L f \times g o v$ & & & $\begin{array}{c}0.211^{* *} \\
(2.33)\end{array}$ \\
\hline$W \times$ lf $\times$ gov & & & $\begin{array}{c}0.309^{* *} \\
(2.04)\end{array}$ \\
\hline Control variables & YES & YES & YES \\
\hline$R 2$ & 0.498 & 0.513 & 0.529 \\
\hline $\log -L$ & 429.51 & 432.19 & 433.28 \\
\hline
\end{tabular}

\subsection{Robustness Test}

In the previous research, this article assumes that the spatial association between regions is mainly a kind of adjacency. It may not reflect the spatial relationship of nonadjacent regions. Therefore, we use the spatial distance weight matrix to redefine the spatial correlation between the two regions and conduct a robustness test [48]. The spatial distance weight matrix is represented by geographic distance if $i \neq j$, then $w=1 / d_{i j}^{2}$, otherwise it is $0 . d_{i j}$ is the geographic distance between different regions. Table 8 is the robustness test of the spatial distance weight matrix. The robustness test results show that the key variables have passed the significance test and are consistent with the signs of the basic regression, which also shows that the research results are robust.

Table 8. Robustness test based on spatial distance weight matrix.

\begin{tabular}{ccccc}
\hline & SLM & Direct Effects & Indirect Effects & Total Effects \\
\hline$L F$ & $0.203^{* *}$ & $-0.130^{* *}$ & $-0.161^{*}$ & $-0.291^{* *}$ \\
& $(2.12)$ & $(-2.27)$ & $(-1.81)$ & $(-2.16)$ \\
Control variables & YES & & & \\
$\rho$ & $0.149^{* * *}$ & & & \\
$R 2$ & $(2.95)$ & & & \\
$L o g-L$ & 0.416 & & & \\
Note: ${ }^{* * *}, * *$ & and ${ }^{*}$ represent significance of $p$-values at 1,5, and $10 \%$, respectively.
\end{tabular}

\subsection{Discussion}

Through empirical testing, it is found that LF has a restraining effect on the growth of the green economy. This is different from the conclusion that Mo (2018) and Song (2020) only consider the economic effects of land property $[9,10]$. After considering the environmental effects of LF, LF inhibits green economic growth. This shows that the local government's land fiscal policy has damaged the ecological environment of the city and affected the growth of the regional green economy. Therefore, the research on the impact 
of LF should not be limited to a single-dimensional study of economic growth. Instead, it is necessary to incorporate undesired outputs such as ecological and environmental protection into the research framework from the perspective of economic efficiency to research the effects of LF. In addition, the impact of LF on the green economy growth has the characteristics of spatial overflow. The local government used LF to make up for the financial funding gap, which not only has a restraining effect on the green economic growth of the region, but also spreads to the surrounding areas. This is similar to Wang et al.'s (2021) research on the spatial effect of LF on China's industrial structure [7]. Therefore, we need to pay attention to the spatial relevance of regional green economic growth. When implementing the development strategy of LF, local governments should consider their own resource conditions and economic cooperation between regions. At the same time, it is necessary to minimize excessive intervention in land resources and reduce the distortion of the allocation of land resources. Finally, we further analyzed the regulatory effect of local government competition on LF. Local government competition has actually strengthened the restraining effect of LF on the growth of the green economy. This is closely related to the performance evaluation of local governments and the evaluation criteria for the promotion of officials. Based on the needs of political promotion and economic growth, officials will spare no effort to use their controllable land resource allocation rights to obtain land benefits, achieve faster economic growth in their jurisdictions and better political performance rankings [42]. Under the influence of imitating competition among governments, the economic development model of LF has an unsustainable development trend, which is contrary to the high-quality development of green economic. Therefore, it is important to strengthen the management of inter-regional government competition, incorporate economic growth and ecological environmental protection into the content of government performance evaluation, and build an evaluation system for local government performance evaluation with the goal of green economic.

\section{Conclusions and Policy Implications}

Land finance and green economic growth are both important economic issues in China. What is the relationship between them? This article uses the panel data of 283 prefecturelevel cities in China from 2009 to 2018 to construct a spatial measurement model to study the impact of LF on the growth of the green economy. The following research conclusions are obtained. First of all, LF has a significant inhibitory effect on the green economy. The direct, indirect and total effects are all significantly negative, which indicates that the local government's means of making up for the financial funding gap through LF not only inhibited the green economic growth in the region, but also had an impact on neighboring areas. Second, in the role of LF on the urban green economy, government competition has a regulating effect, and government competition has actually strengthened the inhibitory effect of LF on green economic growth.

According to the conclusion of this article, we can get the following policy enlightenment.

First of all, LF not only directly inhibits the growth of the green economy in the region, but also adversely affects the neighboring areas. Therefore, it is necessary to further regulate and supervise the land supply behavior of local governments. Local governments should formulate scientific development strategies in accordance with the regional natural conditions, population scale and economic foundation. Make the scale and speed of land supply coincide with the growth rate of urbanization, industrialization and population scale, and prevent the disorderly expansion of cities from causing economic development and ecological environment imbalance. At the same time, it is necessary to regulate and supervise the use of LF by local governments, and to use the land fiscal revenue obtained in the right place, not only to provide support for economic growth, but also to attach importance to the construction of the ecological environment. Avoid the distorted allocation of land resources caused by LF, and improve the sustainable development of urban green 
economy. In addition, it is necessary to guide LF funds to play more active roles in the development of advantageous industries and environmental protection.

Second, because government competition has strengthened the restraining effect of LF on the growth of the green economy. Therefore, the fiscal and taxation system needs to be reformed, the local government performance evaluation and promotion evaluation standards should also be changed. On the one hand, the central government should rationally allocate financial funds among different levels of government to reduce the financial pressure on local governments. On the other hand, it is necessary to incorporate economic growth and ecological environment protection into the content of government assessment, and build a local government performance assessment system with the goal of green economy. In addition, the process of market-oriented reform of land use in China should also be deepened. The government should take value as the direction, and use supply and demand as signals to determine the allocation of land resources and improve the efficiency of allocation.

Finally, due to the local government's over-reliance on land transfer revenue, the central government should continue to improve laws and regulations related to land use. It is necessary to use tax management methods to regulate the land financial model and prohibit local governments from selling land in violation of regulations. At the same time, the efficiency of the use of land transfer revenue by local governments should also be improved to provide a scientific market environment for the rational allocation of land resources. The relationship between land, environment and economy must be correctly handled to achieve high-quality development of the regional green economy.

Author Contributions: S.H.: Model analyses, Data curation, Writing—original draft. L.S.: Writingreview and editing, Supervision, Framework. J.W.: Model analyses, Data curation. S.A.: Model analyses, please turn to the CRediT taxonomy for the term explanation. All authors have read and agreed to the published version of the manuscript.

Funding: This research was funded by the National Natural Science Foundation of China (71871144) and Shanghai Key Discipline (S1201GYXK).

Institutional Review Board Statement: Not applicable.

Informed Consent Statement: Not applicable.

Data Availability Statement: The data supporting the findings of the article is available in the National Bureau of Statistics of China (http:/ / www.stats.gov.cn/, accessed on 2 August 2021) and https: / / www.landchina.com/, accessed on 2 August 2021.

Acknowledgments: We thank Yining Zhang and Jianjia He of the University of Shanghai for Science and Technology for their help in standardizing the content and language of the manuscript.

Conflicts of Interest: No potential conflict of interest are related to this article.

\section{References}

1. Wu, D.; Wang, Y.; Qiao, W. Efficiency evaluation and dynamic evolution of China's regional green economy: A method based on the Super-PEBM model and DEA window analysis. J. Clean. Prod. 2020, 264, 121630. [CrossRef]

2. Loiseau, E.; Saikku, L.; Antikainen, R. Green economy and related concepts: An overview. J. Clean. Prod. 2016, 39, 361-371. [CrossRef]

3. Home, O.; Directorate, E. Towards green growth: Monitoring progress: OECD indicators. OECD 2011, 144, 28-37. [CrossRef]

4. Rahman, M.; Alam, K. Exploring the driving factors of economic growth in the world's largest economies. Heliyon 2021,7 , e07109. [CrossRef] [PubMed]

5. Ding, Y.; McQuoid, A.; Karayalcin, C. Fiscal decentralization, fiscal reform, and economic growth in china. China Econ. Rev. 2019, 53, 152-167. [CrossRef]

6. Canavire, B.G.; Martinez, V.J.; Yedgenov, B. Identifying and disentangling the impact of fiscal decentralization on economic growth. World Dev. 2020, 127, 104742. [CrossRef]

7. Wang, D.; Ren, T.; Zhou, T. Understanding the impact of land finance on industrial structure change in China: Insights from a spatial econometric analysis. Land Use Policy 2021, 103, 105323. [CrossRef]

8. Lin, G.C.S. China's Landed Urbanization: Neoliberalizing Politics, Land Commodification, and Municipal Finance in the Growth of Metropolises. Environ. Plan. A Econ. Space 2014, 8, 1814-1835. [CrossRef] 
9. Song, M.; Ma, X.; Shang, Y.; Zhao, X. Influences of land resource assets on economic growth and fluctuation in China. Resour. Policy 2020, 68, 101779. [CrossRef]

10. Mo, J. Land financing and economic growth: Evidence from Chinese counties. China Econ. Rev. 2018, 50, 218-239. [CrossRef]

11. Artioli, F. Sale of public land as a financing instrument. The unspoken political choices and distributional effects of land-based solutions. Land Use Policy 2021, 104, 105199. [CrossRef]

12. Kalkuhl, M.; Milan, B.F.; Schwerhoff, G.; Jakob, M.; Hahnen, M.; Creutzig, F. Can land taxes foster sustainable development? An assessment of fiscal, distributional and implementation issues. Land Use Policy 2018, 78, 338-352. [CrossRef]

13. Foldvary, F.E.; Minola, L.A. The taxation of land value as the means towards optimal urban development and the extirpation of excessive economic inequality. Land Use Policy 2017, 69, 331-337. [CrossRef]

14. Lichtenberg, E.; Ding, C. Local officials as land developers: Urban spatial expansion in China. J. Urban Econ. 2009, 66, 57-64. [CrossRef]

15. Heikkila, E. Three questions regarding urbanization in China. J. Plan. Educ. Res. 2007, 27, 65-81. [CrossRef]

16. Zhong, T.; Chen, Y.; Huang, X. Impact of land revenue on the urban land growth toward decreasing population density in Jiangsu Province, China. Habitat Int. 2016, 58, 34-41. [CrossRef]

17. Dell'Anno, R. Reconciling empirics on the political economy of the resource curse hypothesis. Evidence from long-run relationships between resource dependence, democracy and economic growth in Iran. Resour. Policy 2020, 68, 101807. [CrossRef]

18. Merino-Saum, A.; Clement, J.; Wyss, R.; Baldi, M.G. Unpacking the Green Economy concept: A quantitative analysis of 140 definitions. J. Clean. Prod. 2019, 242, 118339. [CrossRef]

19. Kim, S.E.; Kim, H.; Chae, Y. A new approach to measuring green growth: Application to the OECD and Korea. Futures 2014, 63, 37-48. [CrossRef]

20. Cheng, X.; Long, R.; Chen, H.; Li, W. Green competitiveness evaluation of provinces in China based on correlation analysis and fuzzy rough set. Ecol. Indic. 2018, 85, 841-852. [CrossRef]

21. Price, L.; Zhou, N.; Fridley, D. Development of a low-carbon indicator system for China. Habitat Int. 2013, 37, 4-21. [CrossRef]

22. Arman, H.; Jamshidi, A.; Hadi-Vencheh, A. Eco-innovation analysis: A data envelopment analysis methodology. Environ. Technol. Innov. 2021, 23, 101770. [CrossRef]

23. Emrouznejad, A.; Yang, G. A survey and analysis of the first 40 years of scholarly literature in DEA:1978-2016. Socio-Econ. Plan. Sci. 2018, 61, 4-8. [CrossRef]

24. Liu, Y.; Dong, F. How technological innovation impacts urban green economy efficiency in emerging economies: A case study of 278 Chinese cities. Resour. Conserv. Recycl. 2021, 169, 105534. [CrossRef]

25. Merino-Saum, A.; Baldi, M.G.; Gunderson, I. Articulating natural resources and sustainable development goals through green economy indicators: A systematic analysis. Resour. Conserv. Recycl. 2018, 139, 90-103. [CrossRef]

26. Belmonte-Urea, L.; Plaza-Beda, J.; Vazquez-Brust, D. Circular economy, degrowth and green growth as pathways for research on sustainable development goals: A global analysis and future agenda. Ecol. Econ. 2021, 185, 107050. [CrossRef]

27. Schiederig, T.; Tietze, F.; Herstatt, C. Green innovation in technology and innovation management-An exploratory literature review. $R$ D Manag. 2012, 42, 180-192. [CrossRef]

28. Meo, M.S.; Karim, M. The role of green finance in reducing CO2 emissions: An empirical analysis. Borsa Istanb. Rev. 2021, 3, 1-10. [CrossRef]

29. Zhang, H.; Zhang, Y.; Chen, T. Land remise income and remise price during China's transitional period from the perspective of fiscal decentralization and economic assessment. Land Use Policy 2016, 50, 293-300. [CrossRef]

30. Wang, L.; Wu, H.; Hao, Y. How does China's land finance affect its carbon emissions? Struct. Chang. Econ. Dyn. 2020, 54, 267-281. [CrossRef]

31. Wassmer, R.W. Fiscalisation of land use, urban growth boundaries and non-central retail sprawl in the western United States. Urban Stud. 2002, 38, 1307-1327. [CrossRef]

32. Weingast, B.R. Second generation fiscal federalism: The implications of fiscal incentives. J. Urban Econ. 2009, 65, $279-293$. [CrossRef]

33. Kahn, M.E.; Sun, W.; Wu, J.; Zheng, S. Do political connections help or hinder urban economic growth? Evidence from 1400 industrial parks in China. J. Urban Econ. 2021, 121, 103289. [CrossRef]

34. Hong, Y.; Lyu, X.; Chen, Y.; Li, W. Industrial agglomeration externalities, local governments' competition and environmental pollution: Evidence from Chinese prefecture-level cities. J. Clean. Prod. 2020, 277, 123455. [CrossRef]

35. Liang, W.; Yan, M. Urbanization, economic growth and environmental pollution: Evidence from China. Sustain. Comput. Inform. Syst. 2019, 21, 1-9. [CrossRef]

36. Kok, N.; Monkkonen, P.; Quigley, J. Land use regulations and the value of land and housing: An intra-metropolitan analysis. J. Urban Econ. 2014, 81, 136-148. [CrossRef]

37. Edward, G.; Huang, W.; Ma, Y.; Shleifer, A. A Real Estate Boom with Chinese Characteristics. J. Econ. Perspect. 2017, 31, 93-116. [CrossRef]

38. Jiang, H. Spatial-temporal differences of industrial land use efficiency and its influencing factors for China's central region: Analyzed by SBM model. Environ. Technol. Innov. 2021, 22, 101489. [CrossRef]

39. Sun, M.; Wang, J.; He, K. Analysis on the urban land resources carrying capacity during urbanization-A case study of Chinese YRD. Appl. Geogr. 2020, 116, 102170. [CrossRef] 
40. Fredriksson, P.G.; Millimet, D.L. Strategic Interaction and the Determination of Environmental Policy across U.S. States. J. Urban Econ. 2002, 51, 101-122. [CrossRef]

41. Oates, W.E.; Schwab, R.M. Economic competition among jurisdictions: Efficiency enhancing or distortion inducing? J. Public Econ. 1988, 35, 333-354. [CrossRef]

42. $\mathrm{Pu}, \mathrm{Z} . ; \mathrm{Fu}, \mathrm{J}$. Economic growth, environmental sustainability and China mayors' promotion. J. Clean. Prod. 2018, 172, 454-465. [CrossRef]

43. Wang, Q.; Yi, H. New energy demonstration program and China's urban green economic growth: Do regional characteristics make a difference? Energy Policy 2021, 151, 112161. [CrossRef]

44. Pittman, R.W. Multilateral Productivity Comparisons with Undesirable Outputs. Econ. J. 1983, 93, 883-891. [CrossRef]

45. Wu, J.; An, Q.; Xiong, B.; Chen, Y. Congestion measurement for regional industries in China: A data envelopment analysis approach with undesirable outputs. Energy Policy 2013, 57, 7-13. [CrossRef]

46. LeSage, J.P.; Pace, R.K. Introduction to Spatial Econometrics; CRC, Taylor \& Francis Group: New York, NY, USA, 2009. [CrossRef]

47. Han, J. Can urban sprawl be the cause of environmental deterioration? Based on the provincial panel data in China. Environ. Res. 2020, 189, 109954. [CrossRef] [PubMed]

48. Paas, T.; Schlitte, F. Regional Income Inequality and Convergence Processes in the EU-25. HWWA Discuss. Pap. 2008, 355, 1-33. Available online: http:/ / hdl.handle.net/10419/19384 (accessed on 6 February 2021). 